\title{
ICDS Scheme to the Growth Development in Preschoolers: A Systematic Review of Literature
}

\author{
Jemy Elizabeth Joseph \\ Medical Science Department, JJT University \\ Vidyanagari, Jhunjhunu, Rajasthan-333001, India
}

\begin{tabular}{l} 
Article Info \\
\hline Article history: \\
Received March 4, 2014 \\
Revised April 25, 2014 \\
Accepted May 26, 2014 \\
\hline
\end{tabular}

Keyword:

ICDS

Preschoolers

Substantial

Intellectual

Convivial

Progression

\begin{abstract}
The health scenario in our country is rapidly changing, both in terms of the public health challenges that we face as well as our response to these challenges. As India becomes more and more developed and we have greater means at our disposal, our response to our health challenges must reflect our changing health and socio-economic status. India faces enormous challenges in the area of women's and children's health. These findings point to the importance of investing in various growth factors and sanitation, and educating the public about hygiene to promote health knowledge and better child outcomes. As importantly, such investments have the potential of making the feeding program more effective. ICDS therefore takes holistic view of the development of the child and attempts to improve both his/her prenatal and postnatal environment. Accordingly, besides children in their formative years ( $0-6$ years), women between 15 to 45 years are also covered by the programme as these are child bearing years in the life of a women and her nutrition and health status has a bearing on the development of the child.
\end{abstract}

Copyright $@ 2014$ Institute of Advanced Engineering and Science. All rights reserved.

\section{Corresponding Author:}

Jemy Elizabeth Joseph, Medical Science Department, JJT University, Vidyanagari, Jhunjhunu, Rajasthan-333001, India.

Email: jemyshiju@gmail.com

\section{INTRODUCTION}

When health improves, life improves by every measure. We have to take the responsibility of the future in terms of making the world a 'Better place' health wise and other wise. India being the second largest populated country in the world and with a multitude of health problems encompassing both communicable and noncommunicable diseases and other public health related problems. India's burden in terms of maternal, new born, and child mortality is one the highest in the world. India has witnessed significant changes in public health, despite signifi cant achievements in some areas. There remain many public health issues that are of immediate concern. India has one of the highest percentages of the severe malnourished children's in the world along with Sub-saharan Africa reigon [1]-[4] .Integrated Child Development Service Scheme is a unique programme, which encompasses the main components of human resource development, namely - health, nutrition and education. The National Policy for children adopted in 1974 has emphasized the need to accord priority to children, in the country's developmental efforts. The Government of India initiated the Integrated Child Development Services (ICDS) Scheme in 1975 to provide nutrition and education services for preschool children, and pregnant and lactating mothers. The objectives of the program are achieved through an integrated package of services including supplementary nutrition, immunization, health check-ups, referrals, non-formal preschool, and health and nutrition education. This integrated approach is delivered through angadwadi centers located in poorer areas that are most in need of primary health care and nutrition. The program is coordinated at the village, block, district, state and central 
government levels. The primary responsibility for implementation lies with the Ministry of Women and Child Development. Although the ICDS scheme is the largest early childhood development program in the world, its success in achieving its primary goal of reduction in child malnutrition has remained uncertain. While the program intends to serve those most in need, there seems to be a gap between program objectives and implementation; even though the ICDS budget was 1.5 billion dollars in 2008. The policy statement focuses on preventive and promotive aspects of child health and nutrition for expectant and nursing mothers. It aims to provide adequate services for children both before and after birth and throughout the period of growth to ensure their full physical, mental and social development. The nations of the world are ranked according to their achievements in fulfillment of child rights and progress for women. A majority of children live in impoverished economic, social and environmental condition, which impedes their physical and mental development. Recognizing the India government has been greatly concerned about safeguarding and enhancing the development of children particularly those from the weaker sections of society [5]-[10]

ICDS therefore takes holistic view of the development of the child and attempts to improve both his/her prenatal and postnatal environment. Accordingly, besides children in their formative years (0-6 years), women between 15 to 45 years are also covered by the programme as these are child bearing years in the life of a women and her nutrition and health status has a bearing on the development of the child. Welfare services for the young child therefore, have become an integral part of the country's developmental plans, At the heart of these lies the Integrated Child Development Services Scheme [11]-[14].

Children's development can be enhanced with appropriate timely and quality programme that provide positive experiences for children and support for parents. Early care and nurturing have a decisive and lasting impact on how children grow to adulthood and how they develop their ability to learn and their capacity to regulate their emotions. Reasonable learning opportunities provided during the Early Childhood years are crucial for the development of Intellectual [14]-[16]. Two environmental factors have the greatest effect on the child's intellectual development. These are nutrition and stimulation, serious and prolonged deprivation of these during early childhood years resuit in almost permanent damage to intellectual growth. Social development is the acquisition of the ability to behave in accordance with social expectations. The forms of social behaviour necessary for successful social adjustment appear and begin to develop at this age. The entire development of the child is very much influenced by its social contact. Physical development applies to all aspects of growth of human organism. Early childhood represents a remarkable period of physical and motor development. Physical development influences the child's behaviour directly or indirectly. Directly it determines what the child can do and indirectly it influences his attitude towards himself and others. Physical growth influences behaviour, thoughts, attitudes, ideals, emotional reactions and activities [17]-[20]

It was launched in 1975 with 33 projects on an experimental basis, ICDS has expanded considerably in subsequent years and at present has 5614 projects in about 45 percent of the community development blocks of the country, comprising of 4571 rural, 733 tribal and 310 urban projects. It is perhaps the only countrywide programme in the world functioning on a large scale, requiring multi-sectoral operations and inter-sectoral linkages for its implementation. It reaches out to 40.37 lakhs expectant and nursing mothers and 214.5 lakh children in the age group 0-6 years through more than 7 lakh frontline workers. It reaches out to 4.83 million expectant and nursing mothers, and 22.9 million young children (under 6 years of age) in disadvantaged community groups. Of these 12,45 million young children (3-6 years of age) also participate in early joyful learning activities through the AWCS spread across the country. A wide network of distributed population based workers have enabled ICDS to emerge as the convergent interface between disadvantaged communities and other programmes such as primary education and health care. It is indeed for our national effort to achieve universalisation of elementary education [21]-[25]

As on 1996, in Kerala there are 120 ICDS blocks (112 rural and 8 urban blocks). ICDS III Project, 2000, which is assisted by the World Bank will bring universalisation of the ICDS programme in Kerala, by including 80 blocks spread over 14 districts of the state (40 rural, 3 urban, 36 coastal and 1 tribal block). There are some studies on the impact of ICDS in Kerala. A study by the Department of Pediatrics of the Medical College, Calicut on the impact of ICDS programme on school drop outs in Calicut (1984); A comparative study of skill development status of Anganwadi pre-schooler children and with a private nursery school in Thiruvananthapuram district, which revealed a higher scare for private nursery school are some of them.

\section{RESEARCH REVIEW}

\subsection{Intellectual Development}

The word 'Intellectual' is a singular noun and is conceived sometimes as having a thing character though whatever we know about anyone's Intellectual is through the observation of his behaviour which is the reflection of his ability [26]-[29].

IJPHS Vol. 3, No. 2, June 2014 : 87 - 94 


\subsubsection{Aspects of Intellectual}

The various aspects of Intellectual (Intellectual) identified by Currie (2002) are verbal comprehension, word fluency, number, space visualization, memory, perceptual speed and reasoning. The Intellectual abilities include memory, creativity, concept development, and association of imagination. According to U.S. Department of Health and Human Services, 1999, 2002, it includes all the mental activity - remembering, symbolising, categorising, problem solving, creating, fantasising and even dreaming. The Intellectual covers areas of sensation, perception, memory, thought, reasoning and language. There are various theories of Intellectual proposed by the psychologists [30]-[32]

\subsubsection{Factors Influencing Intellectual Development in Early Childhood} Heredity

It is from heredity that the child acquires a particular mental level and specific mental abilities [33] Every person is born with a certain mental capacity that influences how intelligent he or she will be as an adult. The development of this capacity is influenced by the person's environment. It have stressed that the inherited Intellectual together with environmental stimulation results in the Intellectual development of the child [34].

\section{Stimulating Environment}

A study by Kennedy and Slack (1993) has demonstrated the influence of environment on the Intellectual development. Volkmar et al., (1990); Tandon and Kapil (1991) have reported that children living in stimulating environments have better Intellectual development (Biriukova, 2005; Nikolaeva, 2008). Every child is born with certain strategies for interacting with the environment. The Intellectual development during early years is rapid, and environment creates a deep impact on the child [34]-[40]

\section{Nursery school}

Children who have nursery, day care and balwadi experiences and those who attend special intervention programmes [41] and Head Start Programmes have revealed that intervention programmes and pre-school experiences enhance the Intellectual development of disadvantaged pre-school children. It is during early childhood years that the child develops the ability to mentally represents objects and events [42]-[46].

\section{Nutrition}

Adjuik et al., 2006 after conducting a study reported that good nutrition significantly improved the children's mental performance for most tasks. Youngsters who are severely matnourished in childhood may be unable to develop their natural abilities. Furthermore, they reported that follow up research suggested that the Intellectual advantages attributed to an improved diet carry over into adolescence and perhaps into adulthood [47]-[50]

\section{Socio-economic status}

Studies by Swami et al., 2001 have revealed that low SES children have IQ scores 10-15 points less than that of the middle class children. The children from high SES families have higher mentioned abilities. But it has been reported that encouraging, supporting and optimal testing conditions enhance the IQ performances of economically deprived children more than middle class children. A study conducted by the National Council of Education Research and Training and Ministry of Human Resource Development (1996) conducted by the Department of Woman and Child development shown a high mean score in the upper middle class, urban lower class coming in between and the rural getting the lowest mean score [51].

\subsection{Convivial Development}

A child is not born Convivial (Social). He learns to be Convivial. A Convivially mature child can adjust well with others, make actions which are beneficial both to himself and to the society, will trust his classmates, solve interpersonal problems in an adaptive way and earn higher grades. The defined Convivial development as the ability to behave in accordance with Convivial expectations [52].

Acquisition of the ability to behave in accordance with Convivial expectations. A less formal definition is learning the rules of the game [53]. It includes three components:

- Learning how to behave: This involve first of all coming to understand what the rules are and then learning to obey them.

- Playing approved Convivial roles: Every group has its own defined roles, that people are expected to play.

- Developing Convivial attitudes: Children realize the value of group membership and feel a need to join.

\subsubsection{Aspects of Convivial Development}

The various aspects of Convivial development are trust, autonomy initiativeness, industry, intimacy, generosity and integrity, friendship, cooperative play, give and take relationship, team spirit and cooperation, negativism, aggression, quarrelling, teasing and bullying, rivalry, cooperation, ascendant behaviour, generosity, desire for Convivial approval, sympathy, dependency and friendliness, sharing, cooperative play, imitation, identification, curiosity, asking questions, competition and sex appropriate behaviours, Altruism, cooperation, sharing, friendship and helping, dependency, autonomy, mastery, competence, friendship, cooperation and popularity (Greene, 2006). A variety of phenomenon like personality traits aggressiveness, altruism, dependent and assertive behaviour, motivation, incentives, the assumptions of rights and responsibilities, Convivial responsiveness, sex and ethnic differences in temperament. Negativism, blind imitation, rivalry, aggression, quarrelling, non-cooperativeness, ascendant behaviour, selfishness, 
sympathy, Convivial approval, sex cleavages, companions, stability of playmates, Convivial acceptability, substitute companions and leadership [54]-[55]. There are various theories on Convivial development has been proposed.

\section{Factors Influencing Convivial Development in Early Childhood}

The host of factors influences the Convivial development in early childhood. They are listed below.

\section{Family}

The family moulds the Convivial behaviour of the child. It directs later Convivialisation, shapes the child's Convivial relationship teaches the child to trust others, develop punctuality and friendship, prepares the child for future, gives security to the child and helps in making adjustments. The early experiences of the child at home and the language spoken in the home influence the child's Convivial development. Children reared in the permissive homes show more confidence, frankness, respect for personality and the ability to face reality [56]-[59].

\section{School}

Teachers play a central role in Convivialising the children. Positive contact with teachers stimulate selfConvivialisation Convivial competence and promote positive Convivial behaviours in children. Children with positive and cooperative contact with class mates develop autonomy have advance Convivial consciousness and are more sociable. It has been proved that the children with enough lave and support with feelings of trust who are popular and children with better communicative skills have better Convivial development, whereas children of unskilled manual workers, disobedient children those with fear of malnourished children and children with academic failure have poor Convivial development [60]-[63].

\section{Culture}

The influence of culture on Convivial development is very extensive covering the personality traits. Some cross-cultural studies have revealed that black children have stronger self concept, more satisfied with their image Inore friendlier and make more cross race relationship [53] than the white children.

\subsection{Substantial Development}

Substantial development is an integral part of the total growth and development of the individual. It is one of the more overt and impressive indications of children's development. It has an important impact on motor and other aspects of development. Skinner (1996) states that the child's Substantial (Physical) development has a marked influence on the quality and quantity of his behaviour. Substantial development is an important aspect of development, because it influences the child's behaviour both directly and indirectly [64-68]. Directly, it determines what the child can do and indirectly it influences his attitudes towards himself and others. Substantial growth as an outcome is important because of the evidence linking poor growth to subsequent morbidity, mortality and lower performance in work capacity and school achievement [69]-[72]. Substantial development refers to increase in bodily tissues and it denotes height and weight changes, changes in body proportions, bone growth, muscular development and development of the nervous system.

\subsubsection{Aspects of Substantial Development}

Because children are constantly growing and changing, it becomes important for health care professionals to assess their progress periodically. Various measures of Substantial growth are valid indicators of past and present nutritional deprivation, and of future outcomes of functional significance, such as school achievement or employment. A complete assessment of nutritional status includes the collection of anthropometric data. According to the Central Technical Committee on Health and Nutrition (AIIMS) various anthropometric measurements of the body can be used to determine growth. Nutritional anthropometry is concerned with the measurements of the variation of Substantial dimension and the QrOSS composition of the human body at different ages. Body weight and height indicate body size. In addition, the head, chest and mid-arm circumferences give an idea of growth and development, especially of small children (0-5 years). Substantial measurements reflect the total nutritional status over a lifetime. Some measurements, such as height and head circumference, reflect past nutrition or chronic nutritional status. Others such as mid-arm circumference, weight and skin fold thickness reflect present nutritional status and are used to assess the skeletal energy reserves both as fat and as protein [70]-[73].

\subsubsection{Factors Influencing Substantial Development in Early Childhood}

\section{Heredity}

Substantial development is influenced to a certain extent by genetic factors [68]. Tall parents usually have tall children and short parents have short children. Therefore, the tendency to be tall or short seems to be largely hereditary when one parent is tall and the other short, the children may be tall or short or midway between. This occurs because the heredity pattern is complex and other factors are often involved [60]

\section{Hormones}

Hormones produced by glands in the body modify growth. Secretions from the pancreas, thyroid g!and and pituitary gland particularly affect growth. These secretions-insulin, thyroxin and growth hormone-greatly influence cell size and cell number. Too little of any of these hormones can slow growth. In hormone deficient patients treatment with 
the particular hormone increases growth. Growth hormone affects the development of almost all body tissues, and thyroxin influences brain growth and body size [55]-[58].

\section{Nutrition}

Nutrition is the science that deals with foods and the way the body uses them. A balanced diet provides all the food substances needed by the body for healthy growth and development. Good nutrition also includes eating the proper amount of food each day. Children who manage to survive extreme forms of malnutrition grow to be smaller in all body dimensions. In addition their brains are seriously affected. Malnutrition probably interferes with rnyelinization causing a permanent loss in brain weight. By the time these youngsters reach middle childhood, they score low Intellectual tests, show poor fine motor co-ordination, and having difficulty paying attention in school [40]. A child who suffers from nutrient deficiencies exhibits Substantial and behavioural symptoms: the child is sick and out of sorts [22].

\section{Exercise}

It is Concluded that Exercise helps keep the body healthy and fit. Vigorous exercise strengthens muscles and improves the function of the circulatory and respiratory systems. Substantial fitness benefits both Substantial and mental health. It enables the body to withstand stresses that otherwise could cause Substantial and emotional problems. If produces superb results in terms of health, and it improves the heart's capacity to do its work. In the body, nutrition and Substantial activity go hand in hand [21]-[23],[44]

\section{Rest and Sleep}

Rest and sleep help .overcome fatigue and restore energy to the body. Pleasurable and relaxing activities help the body shed tension and remain robust (World Book Encyclopaedia, 1992). Life style and quality of food is vital for the Substantial development of a child. Prevention of under nutrition in infants and young children is critical because growth deficits are generally recouped, even with adequate feeding in later years [33]

\section{Stress and Emotional Disturbances}

Frequent stress and emotional disturbances can interfere with Substantial development even in the foetal stage. Emotions influence the secretion of digestive enzymes. Fear and depression decrease secretions and inhibit blood flow and the motility of the elementary canal. Emotional satisfaction stimulate hormonal secretions that contribute to health.

\section{Diseases and Infections}

Diseases and communicable infections can interrupt growth [65]. If the children are not immunised against infectious diseases, they fall an easy prey to disease, and this in turn, is a major cause of malnutrition and through it, affects Substantial growth. Illness reduces appetite, and it limits the body's ability to absorb food cleanliness that children do eat. Immunization controls the growth of bacteria and other germs that can cause disease [10].

\subsection{Integrated Child Development Service Scheme (ICDS)}

In 1974, India adopted the National Policy for children and constituted a National Children Board to ensure continued planning, monitoring and coordination of various welfare services for children. An in-depth assessment of prevailing programmes confirmed the need for a holistic programme to provide an integrated approach to child growth and development.

The scheme has because the single largest child hood intervention programme, presently covering projects spread all over the country. It encompasses human resource development namely health, nutrition education. It was decided that such a programme should have components of health, nutrition, pre-school and non-formal education on health and nutrition. Thus, in pursuance of the National Policy for children, the country's largest programme was launched on the fateful day of 2 Oct. 1975 in 33 experimental blocks6 (4 - urban, 18 -rural, 11 - tribal). By the end of 1995-96, the scheme had spread over 5614 projects (Central - 5103, States - 511) covering nearly 5300 community development blocks and over 300 urban slums. ICDS caters for over 22 million beneficiaries, which include over 18 million children and nearly 4 million pregnant and lactating women ftom the poor socio-economic group. Nearly, 11 million children in the age group of 3-6 years participate in the pre-school education activities at various anganwadi centers. There are over 3 lakh trained anganwadi workers and an equal number of helpers in ICDS services delivery management. Undoubtedly, ICDS is the world's largest programme and it attracts considerable attention of the scientific community all over the world.

Kerala has an excellent record in the field of women and child development. The ICDS scheme started in Kerala, in the year 1975-76 with the establishment of a project in Vengara of the Malabar region, Ever since there was a steady growth of the implementation of ICDS in Kerala. In the first 5 years, 18 projects were established, while in the next 5 year another 53 projects were added. By the year 1991, the total number of projects grew to an impressive 91 . By the year April 96, Kerala had 120 projects sanctioned all of which are currently operational. However, a number of small towns and municipalities remained uncovered by ICDS. ICDS 111 Project (2000) will bring universalisation of ICDS programme in Kerala by including remaining 80 blocks which is not covered by ICDS.

\subsection{Impact of ICDS on Child Beneficiary}

Nair (2000) did a comparative study of skill development status of Anganwadi pre-school children and with a private nursery school in Kerala (Trivandrum Dist.) by using the Nursery Evaluation Scale Trivandrum (NEST). Quality of early childhood environment is also measured by HOME (Home Observation for Measurement of Environment). Inventory associates their moods with colours. It revealed a significant difference. The private nursery school children 
showed higher score. Sood (1992) conducted a study entitled "Women's Status and Child Health." The study revealed that child nutrition varied by state, but narrowly among Convivial groups. Chronic under nutrition declined with increasing age. Kapil (1989) conducted a study entitled "ICDS Scheme-A Programme for Maternal Health and Child Development." The study revealed that it is the largest national programme for the development of mother and children in the world. A study by National Institute of Nutrition (1995) showed that ICDS beneficiaries attained the psychoConvivial developmental milestones at an earlier age than the non-ICDS children. The number of milestones attained by them was also greater. NIN (1999) compared beneficiaries with non-ICDS beneficiaries and found out that beneficiaries scored higher in cognitive test. A study by Sood (1992) has reported that the exposure to ICDS enhanced overall developmental status of the early childhood. In the school performance also, the exposed group was ahead of non-exposed group. Children attending Anganwadi centres performed significantly better than children not attending Anganwadi centres on sequential thinking and time perception aspects of cognitive development. The study was conducted by Kapil (1989) entitled "Impact of ICDS on early childhood Education and Development of Children" The study revealed that the Intellectual status of the children in ICDS villages was definitely better than that of the children in the non-ICDS village and higher Intellectual status in ICDS areas was due to the impact of early childhood education and better nutritional status of children.

Positive impact of nutritional input has been demonstrated in several studies which have reported that a higher percentage of normal children was found in ICDS areas than in non-ICDS areas. found that there was a significant improvement in the average height and weight of children during the repeat survey, which is indicative of the general improvement in Substantial development among children. A comparative study of child health in-ICDS and non-ICDS blocks (0-6 years) was conducted by in Uttar Pradesh also showed a high score for ICDS children.

\section{CONCLUSION}

The review shows that ICDS scheme is very much crucial for the development of Preschoolers. The ICDS Scheme may be very attractive but beneficiaries don't' realize its importance. Standards for AWCs should be formulated and implemented to upgrade them to provide MCH services effectively. Procurement and supply chain system should be strengthened. Clear strategies and procedure for supervision need to be defined along with a list of supervisory activities and the skills for supervision to be taught to the supervisors or personnel who will conduct these activities. Proper and sufficient nutrition supplementation provided to the beneficiaries may help the children towards leading a nutritionally sound and health life combating malnutrition. The ICDS team can help create partnerships between frontline workers and community/women's groups, facilitating an integrated approach for improve childcare, health, nutritional well-being and development. For effective implementation of the programme the ICDS team should make coordinated efforts to deliver the services to the children and mother.

\section{REFERENCES}

[1] Adjuik M., Smith T., Clark S., Todd J., "Cause-specific mortality rates in sub-Saharan Africa and Bangladesh", World Health Organization. Bulletin of the World Health Organization, vol/issue: 84(3), pp. 181-8, 2006.

[2] Afridi F., "Child welfare programs and child nutrition: Evidence from a mandated school meal program in India", Journal of Development Economics. Vol. 92, pp. 152-165, 2010.

[3] Annual Report, Dept, of Women and Child Development, Ministry of HRD, pp. 48, 1998-99.

[4] Arimond M., Ruel T., "Assessing care: Progress towards the measurement of selected child care and feeding practices, and implications for programs”, Washington, DC, USA: Food and Nutrition Technical Assistance Project, Academy for Educational Development, 2002.

[5] Aubel J., Toure I., Diagne M., "Senegalese grandmothers promote improvedmaternal and child nutrition practices: the guardians of tradition are not adverse to change”, Social Science and Medicine, vol/issue: 59(5), pp. 945-959, 2004.

[6] Basile C. G., "Environmental education as a catalyst fortransfer of learning in young children”, Journal of Environmental Education, vol/issue: 32(1), pp. 21-27, 2000.

[7] Bauman A., Bellew B., Vita P., Brown W., Owen N., "Getting Australia Active: Towards better practice for the promotion of physical activity. (Summary)”, Melbourne, Australia: National Public Health Partnership, pp. 109113, 2002.

[8] Bayat M., "Evidence of resilience in families of children with autism”, Journal of Intellectual Disability Research, vol/issue: 51(9), pp. 702-714, 2007.

[9] Berk E. L., “Child development (31d edn.)”, New Delhi, Prentice Hall of India Private Ltd., pp. 218-317, 1996.

[10] Bezner Kerr R., Dakishoni L., Shumba L., Msachi R., Chirwa M., "We Grandmothers Know Plenty: Breastfeeding, complementary feeding and the multifaceted role of grandmothers in Malawi”, Social Science \& Medicine, vol/issue: 66(5), pp. 1095-1105, 2008.

[11] Biriukova N. A., "The formation of an ecologicalconsciousness", Russian Education \& Society, vol/issue: 47(12), pp. 34-35, 2005.

[12] Boyd B. A. "Examining the relationship between stress and lack of social support in mothers of children with autism”, Focus on Autism \& Other Developmental Disabilities, vol/issue: 17(4), pp. 208, 2002.

[13] Bull F. C., Bauman A. E., Bellow B., Brown W., "Getting Australia active II: An update of evidence on phyiscal activity for health”, Melbourne, Australia: National Public Health Partnership, 2004. 
[14] Campbell F. A, Ramey C. T., "Effects of early intervention on intellectual andacademic achievement: a follow-up study of children from low-incomefamilies”, Child Dev, vol. 65, pp. 684-98, 1994.

[15] Carande-Kulis V. G., Maciosek M. V., Briss P. A., "Methods for systematicreviews of economic evaluations for the Guide to Community PreventiveServices”, Am J Prev Med, vol/issue: 18(1), pp. 75-91, 2000.

[16] Chowdhry P., "Training ICDS workers”, Fresh approach needed, Social Welfare, vol/issue: 45(5), pp. 5, 1998.

[17] Cohen J. R., "Exercises in psychological testing and assessment (3rd edn.)”, California, Mayfield Publishing Company, pp. 56, 1996.

[18] Currie J., "Early childhood education programs”, J Emerg Med, vol. 15, pp. 213-38, 2002.

[19] Dasgupta M., Gragnolati M., Ivashenko O., "Improving Child Nutrition? The Integrated Child Development Services in India?”, Development and Change, vol/issue: 36(4), pp. 613-640, 2005.

[20] Davis J., "Young children, environmental education, andthe future", Early Childhood Education Journal, vol/issue: 26(2), pp. 117-123, 1998.

[21] Deutsch F. M., Lussier J. B., Servis L. J., "Husbands at home: Predictors of paternal participationin childcare and housework”, Journal of Personality and Social Psychology, vol/issue: 1(6), pp. 1154-1166, 1993.

[22] Devadas P. R., Jaya N., “A text book on child development”, New Delhi, Macmillan Indian Limited, pp.75, 1996.

[23] Engle P., "Care and Child Nutrition Paper for the International Conference on Nutrition”, UNICEF, New York. Archives of Pediatrics and Adolescent Medicine, vol/issue: 161(8), pp. 730-739, 1992.

[24] Ghosh S., "Second thoughts on growth monitoring”, Indian Pediatrics, vol. 30, pp. 449-453, 1993.

[25] Gopalan C., "Growth charts in primary child health care”, Time for reassessment, NFI Bull, vol/issue: 13(3), pp. 14, 1992.

[26] Greene R. R., “Social work practice: A risk and resilience perspective”, Belmont, CA, Thomson Brooks/Cole, 2006.

[27] Haktanır G., Çabuk B., "National Conference on Child Health Care System Proceedings, Full paper \& Abstract”, pp. s76-81, 2000.

[28] Hands B., Parker H., Glasson C., Brinkman S., Read H., "Physicalactivity and nutrition levels in Western Australian children and adolescents: report”, Perth, Western Australia: Western Australian Government, pp. 190245, 2004.

[29] Horton R, "Maternal and child under nutrition: an urgent opportunity”, Lancet, vol. 371, pp. 179-179, 2008.

[30] Hurlock E. B., "Developmental psychology, A life span approach (5" edn.)”, New Delhi, Tata McGraw Hill Publishing CO. Ltd., pp. 113-116, 1990.

[31] Independent Sport Panel Australian Government, "The future of sport in Australia", Canberra, ACT: Commonwealth of Australia : intervention on adult health and well-being: A 19-year follow-up of low income, pp. 234-289, 2009.

[32] Kandpal E., McNamara P. E., "Persistent Child Malnutrition in India: Evidence from the National Family Health Survey (2005-06)”, Economic and Political Weekly, vol/issue: 6(2), pp. 34-43, 2008.

[33] Kapil U., "Monitoring and Continuing Education System in ICDS scheme. A module for National Health programme”, Indian Pediatrics, vol. 26, pp. 863-867, 1989.

[34] Kennedy E., Slack A., "The integrated child development services (ICDS)", India Lessons learned and Implications for Future Policies. International Food Policy Research Institute, Washinton DC, pp 1211-1453, 1993.

[35] Kidd A. H., Kidd R. M., “Social and environmental influences on children’s attitudes toward pets”, Psycholojical Reports, vol. 76, pp. 807-818, 1990.

[36] Law C., "Adult obesity and growth in childhood: children who grow rapidly during childhood are more likely to be obese as adults”, British Medical Journal, vol/issue: 323(7325), pp. 678-688, 2001.

[37] Malina R., "Tracking of physical activity across the lifespan”, President's Council on Physical Fitness and Sports: Research Digest, vol/issue: 3(14), pp. 1-8, 2001.

[38] Marcus L. M., Kunce L. J., Schopler E., Working with families. In F.R, 2005.

[39] Martorell R., "Undernutrition during pregnancy and early child hood: Consequences for cognitive and behavioural development, Amsterdam”, Elsevier, vol. 21, pp. 39-83, 1997.

[40] Miles L., "Physical activity and health", Nutrition Bulletin, vol/issue: 32(4), pp. 314-363, 2007.

[41] Ministry of Human Resource Development, "Department of Women and Child Development. Annual Report 199596, Part IV”, Government of India Press, New Delhi, pp. 6-9, 1996.

[42] Nair C. K. M., "Health as an entry point for early childhood care - county example of India (Abstract)", Trivandrum, Child Development Centre, Medical College, 2000.

[43] National Statistics Office (NSO), "Malawi demographic and health survey 2010”, Zomba, Malawi: Malawi National Statistics Office (NSO), 2011.

[44] Nikolaeva S., “The ecological education of preschoolchildren”,. Russian Education \& Society, vol/issue: 50(3), pp. 64-72, 2008. doi:10.2753/RES1060.

[45] NIN, "ICDS and Psychosocial Development”, Nutrition News, vol/issue: 16(2), pp. 1-2, 1995.

[46] Osmani S., Sen A., "The hidden penalties of gender inequality: Fetal origins of ill-health”, Economics and Human Biology, vol/issue: 1(1), pp. 105-121, 2003.

[47] Plant K. M., Sanders M. R., "Predictors of care-giver stress in families of preschool-aged children with developmental disabilities”, Journal of Intellectual Disability Research, vol/issue: 51(2), pp. 109-124, 2007.

[48] Pollit E., Gorman K. S., Engle P. L., Martorell R., "Early supplementary feeding and cognition: effects ver two decades, society for research in child development, Amsterdam”, Elsevier, vol. 58, pp. 1-99, 1993. 
[49] Reynolds A. J., Temple J. A., Ou S. R., Robertson D. L., Mersky J. P., Topitzes J. W., Niles M.D., “Effects of a school-based, early childhood”, 2007.

[50] Ruel M. T., "Urbanization in Latin America: Constraints and opportunities for child feeding and care”, Food and Nutrition Bulletin, vol/issue: 21(1), pp. 12-24, 2000.

[51] Ruel M. T., “Operationalizing dietary diversity: a review of measurement issues and research priorities”, The Journal of Nutrition, vol/issue: 133(11), pp. 3911-3926, 2003.

[52] Rushton S., Larkin E., "Shaping the learning environment: Connecting developmentally appropriate practices to brain research”, Early Childhood Education Journal, vol/issue: 29(1), pp. 25-33, 2001.

[53] Rutter M., "The interplay of nature, nurture and developmental influences: The challenge ahead for mental health", Archives of General Psychiatry, vol. 59, pp. 11, 2002.

[54] Samuelsson P. I., Kaga Y., "The contribution of early childhood education to a sustainable society”, UNESCO, Paris, 2008.

[55] Sharma R. N., “Child Psychology”, New Delhi, Surjeet Publications, pp. 110, 1998.

[56] Shi L., Zhang J., "Recent evidence of the effectiveness of educational interventions for improving complementary feeding practices in developing countries”, Journal of Tropical Pediatrics, vol/issue: 57(2), pp. 91-98, 2011.

[57] Shilton T., Naughton G., "Physical activity and children - a statement of importance and call to action from the Heart Foundation”, 2001. http://fulltext.ausport.gov.au/fulltext/2001/nhf/call_to_action.asp

[58] Sizer F., Whitney E., "Nutrition-Concepts and Contraversies (6 edn.)”, New York, West Publishing Co, pp. 357, 1994.

[59] Skinner E. C., “Educational Psychology”, New Delhi, Prentice Hall of India Ltd, pp. 529-293, 1996.

[60] Sood N., "Pre-school education in ICDS”, An appraisal, Delhi, NIPCCID, pp. 46-48, 1992.

[61] Srilakshmi B., "Dietetics”, New Delhi, New Age International Pvt. Ltd, pp. 47-48, 1998.

[62] Swami H. M., Thakur J. S., Bhatia S. P., Bhatia V., "Nutritional status of pre-school children in Integrated Child Development Service (ICDS) block of Chandigarh”, Journal of the Indian Medical Association, vol/issue: 99(10), pp. 554-556, 2001.

[63] Tandon B. N., Kapil U., "ICDS scheme. A programme for development of mother and child health", Indian Pediatrics, vol. 28, pp. 1425- 1428, 1991.

[64] Trost S. G., "Discussion paper for the development of recommendations for children's and youths' participation in health promoting physical activity”, Canberra: Department of Health and Ageing, Australian Government, 2003.

[65] Twoy R., Connolly P. M., Novak J. M., “Coping strategies used by parents of children with autism”, Journal of the American Academy of Nurse Practitioners, vol/issue: 19(5), pp. 251-260, 2007.

[66] U.S. Department of Health and Human Services, "The first progress report on Head Start program performance measures”, Washington, DC: Government Printing Office, 1999.

[67] Victoria C., Huttly S., Barros F.C., Lombardi C., Vaughn J. P., "Maternal education in relation to early and late child health outcomes: Finding from a Brazilian cohort study”, Social Science \& Medicine, vol/issue: 34(8), pp. 899-905, 1992.

[68] Volkmar R., Paul A., Klin, D. Cohen (Eds), "Handbook of Autism and Pervasive Developmental Disorders (3rd edition)”, Hoboken, NJ, John Wiley \& Sons, Inc, pp. 1055-1086, 1992.

[69] Vyas J. N., “Child Psychology”, Bikaner, Medi World Press, pp. 126-135, 1994.

[70] Wilford R., Golden K., Walker D. G., "Cost-effectiveness of community-based management of acute malnutrition in Malawi”, Health policy and planning, vol/issue: 27(2), pp. 127-137, 2012.

[71] Williams C. L., Hayman L. L., Daniels S. R., Robinson T. N., Steinberger J., Paridon S., Bazzarre T., "Cardiovascular health in childhood: A statement for health professionals from the Committee on Atherosclerosis, Hypertension, and Obesity in the Young (AHOY) of the Council on Cardiovascular Disease in the Young, American Heart Association”, Journal of the American Heart Association,. Vol. 106, pp. 143-160, 2002.

[72] Wood L., D'Arcy M., "Active communities - a concept to promote physical activity at the community level in WA", Why the need for people to be more physically active?, 2001. http://fulltext.ausport.gov.au/fulltext/2001/wa/actcom.pdf.

[73] Yang X., Telama R., Leskinen E., Mansikkaniemi K., Viikari J., Raitakari O. T. "Testing a model of physical activity and obesity tracking from youth to adulthood: The cardiovascular risk in young Finns study”, International Journal of Obesity, vol. 31, pp. 521-527, 2007. 